\title{
Analysis Of Hospital Health Care, Health Facilities Level I Of BPJS Patients Satisfaction In Sikumana Public Health Centre Kupang
}

\begin{abstract}
Oktaviana Manek
Magister of Public Health Program of Institut Ilmu Kesehatan STRADA Indonesia

Email:

publikasistrada@gmail.com

Received: October 12, 2019

ABSTRACT

Good health care is a community need and is often a measure of development success. The purpose of this study was to analyze inpatient health care service level I to the satisfaction of BPJS patients in the Sikumana Health Center in Kupang City. The study was conducted at the Sikumana Community Health Center in Kupang City from 15 October to 10 November 2019. The research design used was a qualitative study using a cross sectional approach. The independent variable is health service and the dependent variable is patient satisfaction. The population of all BPJS patients in the Sikumana Kupang health center in the January-August period was 230 respondents. The sampling technique used was Simple Random Sampling with a sample of 146 respondents data analysis techniques using the Logistic regression test. The results of the study of 146 respondents the majority $(56.2 \%)$ of respondents were very satisfied with the service of nurses, there were 82 research subjects, the majority $(58.9 \%)$ of respondents were very satisfied with the service of doctors namely there were 86 research subjects and the majority $(56,2 \%)$ respondents are very Satisfied with Nurse services, there are 82 research subjects, almost half $(45.9 \%)$ respondents get good service based on Tangibels, almost half $(43.2 \%)$ respondents get good service based on reliability, most $(54.1 \%)$ respondents get good service based on Responsiveness, almost half (46.6\%) respondents get good service based on Assurance and almost half (44.5\%) respondents get good service based on Empathy. Logistic regression data analysis concluded that BPJS patient satisfaction based on health services at the Community Health Center in Sikumana, Kupang, obtained a p value of 0.002 because $p$ value $<\alpha(0.05)$ It is expected that research sites will improve the cleanliness of the ward each morning before the examination and in the afternoon, especially the bathroom of the patient and the staff must be diligent in controlling hygiene
\end{abstract}

Accepted : February 13, 2020

Published : May 12, 2020
Keywords: BPJS, Patient Satisfaction, Health Services

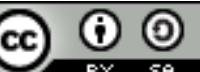

This is an open-acces article distributed under the terms of the Creative Commons Attribution-ShareAlike 4.0 International License. 


\section{INTRODUCTION}

Good health care is a community need and is often a measure of development success. The government has tried from time to time to produce programs that can improve overall health services. One of the programs organized is the National Health Insurance (JKN) run by the Social Security Implementing Agency (BPJS) Health.1 According to the results of the official BPJS website release on February 20, 2018, there were 138,136,660 people who had become BPJS participants with the most use of facilities is at Community Health Centers (puskesmas) with a total of 9799 puskesmas as of February 1, 2018. This causes puskesmas to rank first as health facilities serving BPJS patients

Health centers in the flow of health services are the spearhead of primary level health services before patients get referral health services to hospitals as secondary health services from BPJS-based health care patterns. One of the government's breakthrough efforts to ensure equitable access to health care services is to complete national health insurance programs, which will begin in early 2014, as part of the government's solution to equalize health services for the people of Indonesia. In accordance with Law No. 36/2009 on health, it is emphasized that everyone has the same right to obtain access to resources in the health sector and obtain safe, quality and affordable health services. In 2004 the government issued Law No.40 on the national social security system (SJSM) which stressed that mandatory social security for all residents, including national health insurance (JKN) through a Social Security Management Agency (BPJS). The appointment of BPJS as implementing the JKN was based by Law No. 24/2011 (Adik Wibowo \& TIM. Community health in Indonesia, concepts, applications, challenges in 2014. Pages 477-478). The National Health Insurance (JKN) is a health protection system so that participants benefit from health care and protection in meeting basic needs his health. The government mandates that the participation of the JKN system is mandatory for all Indonesian citizens with the aim that all residents can maintain and meet their health needs at an affordable cost (MOH RI, 2013).

Patient satisfaction is the first indicator of a hospital standard and a measure of service quality. Low patient satisfaction will have an impact on the number of hospital visits, while employee attitudes toward patients will also have an impact on patient satisfaction where the patient's needs will from time to time increase, as will his demands for the quality of services provided. Pursuant to Article 5 paragraph (1) and Article 52 of Law Number 40 of 2004 concerning the National Social Security System, a Social Security Organizing Agency (BPJS) must be formed with a Law which is the fourth transformation of a State-Owned Enterprise to accelerate the implementation of a social security system national for all Indonesian people. Therefore, a BPJS was formed based on the Law of the Republic of Indonesia Number 24 of 2011 concerning the Social Security Organizing Body which began operating in 2014 (Novita, 2016) According to Pratiwi et al (2014) satisfaction is the result of consumer evaluation (assessment) of various aspects of service quality. Stating service quality must begin with consumer needs and end with consumer perceptions (Tjiptono and Chandra, 2011). Patient or participant insurance satisfaction is one factor that can be used as a reference in determining the success of a service program. Besides that, according to presidential regulation number 12 of 2013 article 42 states that the implementation of health services for JKN participants must pay attention to the quality of service and be oriented to patient safety, service effectiveness, compliance with patient needs, and cost efficiency

Participant satisfaction is influenced by several aspects, one of which is the patient demographic factor. According to Schoenfelder et al (2010) demographic factors that are significantly related to patient satisfaction include age, sex, social status, education, where age and education have a strong relationship with patient satisfaction. According to the research of Montol et al (2014) and Stefan et al (2014), patient demographics namely education and income have a significant relationship with patient satisfaction when receiving services at the Puskesmas. At this time in neighboring Canada (the United States) is said to have an inpatient national health insurance for residents over 65 years (elderly) is called medicare part A. Because JKN in the United States only applies to the elderly population, not all Americans under the age of 65 years who have health insurance and around 2013 the population of the United States who have health insurance is still in the range of $15 \%-25 \%$ (According to Hasbula Thabrany, 2015)

Based on 2014-2018 BPJS data, the prevalence of patient satisfaction using BPJS was $78.6 \%$ and also based on the latest data in 2019, patient satisfaction using BPJS as much as $85 \%$, so that in Indonesia there was an increase in BPJS satisfaction in using BPJS in health facilities. processing of 
health insurance programs and financial reports for 2016.) According to Riskesdas 2018, public health services with a healthy Indonesia program are intended to improve the quality of life of Indonesian people in 2018, there are 23,039 first level health facilities (FKTP) and 2,465 advanced referral facilities (FKRTL) that have been built. The population of Indonesia, which has become the national health insurance (JKN) of 208.7 million people, has received a contribution of around 92 million. Health care facilities ranging from $73.50 \%$ were declining compared to 2017 which was $83.67 \%$. Based on a preliminary study conducted at the Sikumana Community Health Center in Kupang City on June 24, 2019 there were 7 BPJS patients who visited and the results were 5 people said the medical staff were less friendly and 2 others said they were not satisfied with the health services at the Sikumana Health Center in Kupang City. Sikumana Community Health Center is located in Maulafa District, Kupang City which has 5 Supporting Health Centers (PUSTU) and 2 Family Health Centers (PUSKESKEL). BPJS participants registered at the Sikumana Health Center in Kupang City were 5,212 BPJS participants with an average visit of 50 people every day. Because of the comparison between the number of participants and the average number of different visits the study was interested in knowing the quality of health services to the satisfaction of BPJS Level I FASKES I participants in the Sikumana Health Center in Kupang City Based on the description above, the authors propose the title "Analysis of Inpatient Health Services at Health Facilities I Level Against BPJS Patient Satisfaction in the Sikumana Health Center in Kupang City".

\section{METHODS}

This research use cross sectional with sample 146 respondent / erderly by Simple accidental sampling. Independent variable (Pelayanan Kesehatan X1. Reability, X2. Responsivennes, X.3 Asurance, X4. Empathy and X5. Tangibels to the dependent variable (Kepuasaan Pasien BPJS Y1. Pelayanan Dokter, Y2. Pelayanan Perawat dan Y3. Pelayanan Administrasi) by using questionnaire in Puskesmas Sikumana Kota Kupang in November 2019. Data were processed and analyzed Bivariate by ordinal regression test.

\section{RESULTS}

Description of Place of Study

Result Overview of PONED Sikumana Community Health Center in Kupang City, Address of Sikumana Village, Maulafa Subdistrict, Kupang City

\section{Descriptive Public Data}

Table 1 Distribution Frequency Characteristics of Respondents in Puskesmas Sikumana Kota Kupang 2019.

\begin{tabular}{llll}
\hline No & Characteristic & $(\mathrm{f})$ & $(\%)$ \\
\hline 1 & $<20$ years & 19 & 13,0 \\
\hline 2 & $20-35$ years & 72 & 49,3 \\
\hline & $>35$ years & 55 & 37,7 \\
\hline & Total & 146 & 100,0 \\
\hline 1 & No School & 8 & 5,5 \\
\hline 2 & SD & 14 & 9,6 \\
\hline 3 & SMP & 50 & 34,2 \\
\hline 4 & SMA & 68 & 46,6 \\
\hline 5 & PT & 6 & 4.1 \\
\hline & Total & 146 & 100.0 \\
\hline 1 & Not Working & 7 & 4,8 \\
\hline 2 & IRT & 53 & 36,3 \\
\hline 3 & The farmer & 4 & 2,7 \\
\hline 4 & Private & 62 & 42,5 \\
\hline 5 & Enterpreneur & 18 & 12,3 \\
\hline 6 & PNS & 2 & 1,4 \\
\hline
\end{tabular}




\begin{tabular}{llll}
\hline & Total & 146 & 100.0 \\
\hline 1 & Man & 92 & 63 \\
\hline 2 & Women & 54 & 37 \\
\hline & Total & 146 & 100,0 \\
\hline
\end{tabular}

Source : Primary Data (2019)

Based on the results of the study of table 1 of 146 respondents it was mentioned that Age description results show that there are 72 research subjects who have aged 20-35 years (49.3\%), education description results indicate that there are 68 research subjects with high school education (46.6\%), Job description results show that there are 62 subjects research working as a private sector $(42.5 \%)$, the results of the description of the sex show that there are 92 research subjects are male (63\%)

Custom Data

Table 2 Distribution Frequency Respondents Based on Special Data in Puskesmas Sikumana Kota Kupang 2019.

\begin{tabular}{|c|c|c|c|}
\hline No & Patient Satisfied (Nurse service) & (f) & $(\%)$ \\
\hline 1 & Very Satisfied & 82 & 56.2 \\
\hline 2 & Satisfied & 43 & 29,5 \\
\hline \multirow[t]{2}{*}{3} & No Satisfied & 21 & 14,4 \\
\hline & Total & 146 & 100.0 \\
\hline No & Patient Satisfied (Dokter service) & (f) & $(\%)$ \\
\hline 1 & Very Satisfied & 86 & 58,9 \\
\hline 2 & Satisfied & 47 & 32,2 \\
\hline \multirow[t]{2}{*}{3} & No Satisfied & 13 & 8,9 \\
\hline & Total & 146 & 100.0 \\
\hline No & Patient Satisfied (Administration service) & (f) & $(\%)$ \\
\hline 1 & Very Satisfied & 101 & 69,2 \\
\hline 2 & Satisfied & 45 & 30,8 \\
\hline \multirow[t]{2}{*}{3} & No Satisfied & 0 & 0 \\
\hline & Total & 146 & 100.0 \\
\hline No & Health Services (Tangibels) & (f) & $(\%)$ \\
\hline 1 & Very Good & 44 & 30,1 \\
\hline 2 & Good & 67 & 45.9 \\
\hline 3 & Not Good & 35 & 24 \\
\hline \multirow[t]{2}{*}{4} & Very Not Good & 0 & 0 \\
\hline & Total & 146 & 100.0 \\
\hline No & Health Services (Reability) & (f) & $(\%)$ \\
\hline 1 & Very Good & 40 & 27,4 \\
\hline 2 & Good & 63 & 43,2 \\
\hline 3 & Not Good & 40 & 27,4 \\
\hline \multirow[t]{2}{*}{4} & Very Not Good & 3 & 2,1 \\
\hline & Total & 146 & 100.0 \\
\hline No & Health Services (Responsiveness) & (f) & $(\%)$ \\
\hline 1 & Very Good & 10 & 6,8 \\
\hline 2 & Good & 79 & 54,1 \\
\hline 3 & Not Good & 44 & 30,1 \\
\hline \multirow[t]{2}{*}{4} & Very Not Good & 13 & 8,9 \\
\hline & Total & 146 & 100.0 \\
\hline
\end{tabular}




\begin{tabular}{llll}
\hline No & Health Services (Assurance) & $\mathbf{( f )}$ & $\mathbf{( \% )}$ \\
\hline 1 & Very Good & 7 & 4,8 \\
\hline 2 & Good & 68 & 46,6 \\
\hline 3 & Not Good & 53 & 36,3 \\
\hline 4 & Very Not Good & 18 & 12,3 \\
\hline & Total & 146 & 100.0 \\
\hline No & Health Services (Empathy) & $\mathbf{( f )}$ & $\mathbf{( \% )}$ \\
\hline 1 & Very Good & 43 & 29,5 \\
\hline 2 & Good & 65 & 44,5 \\
\hline 3 & Not Good & 38 & 26 \\
\hline 4 & Very Not Good & 0 & 0 \\
\hline & Total & 146 & 100.0 \\
\hline
\end{tabular}

Source : Primary Data (2019)

The results of BPJS patient satisfaction description of Nurse services showed that the majority (56.2\%) of respondents were very Satisfied with BPJS services towards Nurse services, namely there were 82 research subjects. The results of BPJS patient satisfaction description of the doctor's services showed that the majority $(58.9 \%)$ of respondents were very satisfied with the service of BPJS to the doctor's services, that there were 86 research subjects. The description of BPJS patient satisfaction with Administrative services shows that the majority (69.2\%) of respondents are very satisfied with BPJS services with Administrative services, namely that there are 101 research subjects, it can be concluded that health services based on Tangibels obtained data that almost half (45.9\% ) respondents get good services based on Tangibels, health services based on Reability data show that almost half (43.2\%) respondents get good services based on Reability, health services based on Responsiveness get data that most $(54.1 \%)$ respondents get services good based on Responsiveness, health services based on Assurance obtained data that almost half $(46.6 \%)$ of respondents received good services based on Assurance, health services based on Empathy obtained data that almost half (44.5\%) respondents got good services based on based on Empathy

Table 3 Cross tabulation of Satisfaction of Nurses' services with health services based on Tangibels aspects of BPJS patients at the Sikumana Health Center in Kupang City October to November 2019

\begin{tabular}{|c|c|c|c|c|c|c|c|c|c|}
\hline \multirow{3}{*}{ Tangibels } & \multicolumn{4}{|c|}{ Satisfaction of Nurses' services } & \multicolumn{5}{|c|}{ Total } \\
\hline & \multicolumn{2}{|c|}{$\begin{array}{l}\text { Very } \\
\text { satisfaction }\end{array}$} & \multicolumn{2}{|c|}{ Satisfaction } & \multicolumn{2}{|c|}{$\begin{array}{l}\text { No } \\
\text { satisfaction }\end{array}$} & & & \\
\hline & $\sum$ & $\%$ & $\sum$ & $\%$ & $\sum$ & $\%$ & $\sum$ & $\%$ & \\
\hline Not Good & 22 & 15,1 & 37 & 25,3 & 23 & 15,8 & 82 & 56,2 & \\
\hline Good & 11 & 7,5 & 16 & 11 & 16 & 11 & 43 & 29,5 & \\
\hline Very Good & 2 & 1,4 & 14 & 9,6 & 5 & 3,4 & 21 & 14,4 & \\
\hline Total & & 35 & 24 & 67 & 45,9 & 44 & 30,1 & 146 & 100 \\
\hline
\end{tabular}

Source : Primary Data (2019)

Based on the table 3 shows a small proportion (25.3\%) of respondents who have satisfaction with the service of nurses with the category of being satisfied getting health services based on good tangibels aspects, namely 37 people 
Table 4 Cross tabulation Satisfaction of nurse services with health services based on aspects of reliability of BPJS patients at the Sikumana Health Center in Kupang City October to November 2019

\begin{tabular}{lllllllll}
\hline \multirow{2}{*}{ Reability } & \multicolumn{7}{c}{ Satisfaction of Nurses' services Total } \\
\cline { 2 - 9 } & $\begin{array}{l}\text { Very } \\
\text { satisfaction }\end{array}$ & \multicolumn{2}{c}{ Satisfaction } & $\begin{array}{l}\text { No } \\
\text { satisfaction }\end{array}$ \\
\cline { 2 - 10 } & $\sum$ & $\%$ & $\sum$ & $\%$ & $\sum$ & $\%$ & $\sum$ & $\%$ \\
\hline Very Not Good & 1 & 0,7 & 2 & 1,4 & 0 & 0 & 3 & 2.1 \\
Not Good & 25 & 17,1 & 7 & 4,8 & 8 & 5,5 & 40 & 27,4 \\
Good & 33 & 22,6 & 23 & 15,8 & 7 & 4,8 & 63 & 43,2 \\
Very Good & 23 & 15,8 & 11 & 7,5 & 6 & 4,1 & 40 & 27,4 \\
\hline Total & 82 & 56,2 & 43 & 9,5 & 21 & 14,4 & 146 & 100 \\
\hline
\end{tabular}

Source : Primary Data (2019)

Based on Table 4 shows a small portion (22.6\%) of respondents who have satisfaction with the services of doctors with a very satisfied category to get health services based on aspects of good reliability that is 33 people

Table 5 Cross tabulation Satisfaction of nurses' services with health services based on aspects of responsiveness in BPJS patients in Sikumana Health Center, Kupang City, October to November 2019

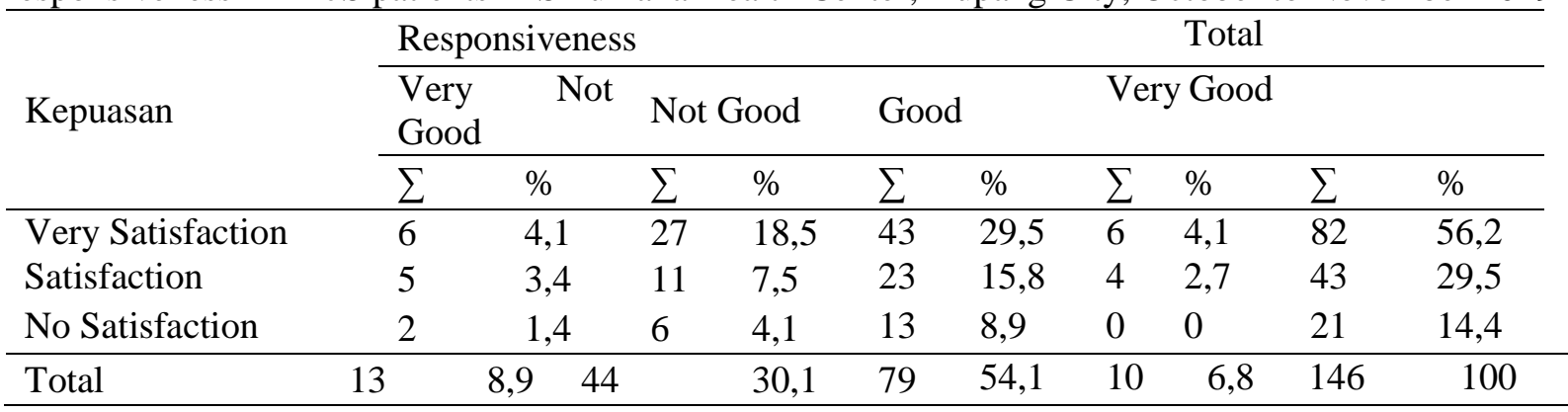

Source : Primary Data (2019)

Based on table 5 shows almost half (29.5\%) of respondents who have satisfaction with nurse services with a very satisfied category to get health services based on aspects of good responsiveness that is 43 people

Table 6 Cross tabulation Satisfaction of nurse services with health services based on aspects of Assurance for BPJS patients in the Sikumana Health Center in Kupang City October to November 2019

\begin{tabular}{|c|c|c|c|c|c|c|c|c|}
\hline \multirow{3}{*}{ Assurance } & \multicolumn{7}{|c|}{ Satisfaction } & \multirow[t]{2}{*}{ Total } \\
\hline & \multicolumn{2}{|c|}{$\begin{array}{l}\text { Very } \\
\text { Satisfaction }\end{array}$} & \multicolumn{2}{|c|}{ Satisfaction } & \multicolumn{2}{|c|}{$\begin{array}{l}\text { Not } \\
\text { Satisfaction } \\
\end{array}$} & & \\
\hline & $\sum$ & $\%$ & $\sum$ & $\%$ & $\sum$ & $\%$ & $\sum$ & $\%$ \\
\hline Very Not Good & 13 & 8.9 & 3 & 2,1 & 2 & 1,4 & 18 & 12,3 \\
\hline Not Good & 28 & 19,2 & 16 & 11 & 9 & 6,2 & 53 & 36,3 \\
\hline Good & 38 & 26 & 21 & 14,4 & 9 & 6,2 & 68 & 46,6 \\
\hline Very Good & 3 & 2,1 & 3 & 2,1 & 1 & 0,7 & 7 & 4,8 \\
\hline Total & 82 & 56,2 & 43 & 29,5 & 21 & 14,4 & 146 & 100 \\
\hline
\end{tabular}

Source : Primary Data (2019)

Based on table 6 shows a small portion (26\%) of respondents who have satisfaction with nurse services with a very satisfied category to get health services based on aspects of good Assurance of 38 people 
Table 7 Cross tabulation Satisfaction of nurse services with health services based on Empathy aspects of BPJS patients at the Sikumana Health Center in Kupang City October to November 2019

\begin{tabular}{|c|c|c|c|c|c|c|c|c|}
\hline \multirow{3}{*}{ Empathy } & \multicolumn{8}{|c|}{ Satisfaction of Nurses' services } \\
\hline & \multicolumn{2}{|c|}{$\begin{array}{l}\text { Very } \\
\text { Satisfaction }\end{array}$} & \multicolumn{2}{|c|}{ Satisfaction } & \multicolumn{4}{|c|}{$\begin{array}{l}\text { Not } \\
\text { Satisfaction }\end{array}$} \\
\hline & $\sum$ & $\%$ & $\sum$ & $\%$ & $\sum$ & $\%$ & $\sum$ & $\%$ \\
\hline Very Not Good & 19 & 13 & 15 & 10,3 & $\overline{4}$ & 2,7 & 38 & 26 \\
\hline Not Good & 37 & 25,3 & 18 & 12,3 & 10 & 6,8 & 65 & 44,5 \\
\hline Good & 26 & 17,8 & 10 & 6,8 & 7 & 4,8 & 43 & 29,5 \\
\hline Total & 82 & 56,2 & 43 & 29,5 & 21 & 14,4 & 146 & 100 \\
\hline
\end{tabular}

Source : Primary Data (2019)

Based on Table 7 shows almost half $(25.3 \%)$ of respondents who have satisfaction with nurse services with a very satisfied category to get health services based on empathy aspects that are not good, 37 people

\section{Bivariate analyze (Ordinal Regression)}

Test Statistics Thus it can be interpreted that with two variables, namely X1 (Satisfaction) and X2 (Health Services), BPJS patient satisfaction can be explained by $56 \%$ ).

\section{DISCUSSION}

Relationship of health services with patient satisfaction Based on the data above opinions that can be concluded by researchers are the results of the study showed almost all respondents from the BPJS group, including being satisfied with health services. This can be caused by various factors. Referring to the existing theory that satisfaction will be realized if the customer or patient gets the service according to or exceeding their wishes or expectations. Generally patients who come expect a quick service, friendly officers in providing services, physical appearance looks good, clean, neat and convincing and can be trusted, impressed with expertise and knowledge that suits the needs of patients, also patients find it easy to get any service, as ethics officers also look polite, there is respect and sincerity in serving patients. This impression is the first thing recorded by a patient that can affect patient satisfaction. Another factor that influences patient satisfaction is educational background. The theory explains that the level of education will tend to help someone in making an assessment of a material or object. Based on the results of previous studies that respondents with low levels of education will feel more satisfied. Based on the analysis it is known that almost half of the BPJS group respondents have a high school education. This can be interpreted with high school education, so the level of education is not too high so that the standard demands for services are not too high, so the services received can already meet expectations or even exceed expectations. of his life will also be achieved.

Based on the results of the analysis above, the researcher can conclude that almost all BPJS group respondents are aged 20-35 years. It can be interpreted that this age is classified as an adult age and is quite mature, so that it is able to place itself in the existing services and not too demanding more services from officers. Another factor that can affect patient satisfaction is work background. Based on the analysis results it is known that almost half of the BPJS group respondents are housewives. As a housewife can generally be assumed to have limited knowledge, insight, and demands for highly quality services. It can be interpreted that the service received in the end can satisfy its customers Based on the data above, the researcher can conclude that almost half (36.3\%) of respondents who have satisfaction with the category of being satisfied getting health services based on aspects of good responsiveness are 53 people Based on the above data, the researchers can conclude that a small proportion of respondents who have satisfaction with the category of being satisfied get health services based on good aspects of Assurance, 41 people. Based on survey of customer satisfaction through the level of conformity of the indicators of trust that most influential on inpatient satisfaction is an indicator of kindness, this is 
because the Puskesmas continues to provide care and treatment to patients who receive patients using BPJS. Good communication is a patient's expectation. The results showed that the communication of doctors who handled when taking blood samples made patients a little uncomfortable because of poor communication. Doctor competence makes patients satisfied because they can handle patient complaints well From the above data, the researcher can conclude that almost half of respondents who are satisfied with the category of being satisfied get health services based on good empathy aspects, that is 45 people. Dimensions of attention at the Sikumana City Health Center in Kupang include services that do not discriminate regardless of social status, officers take special time to communicate with patients, visiting hours (visits), when patients and families consult with doctors, hospitality staff. This dimension shows the attention given to each customer (patient) and reflects the ability of employees to dive into the feelings of the customer (patient)

\section{CONCLUSION}

Patient Satisfaction based on physical form (Tangibles) at the Sikumana Health Center in Kupang City can be explained that the lower health services based on tangibles will have a risk of dissatisfaction 0.5 times higher than those who have health services based on tangibles

Patient Satisfaction based on Reliability at the Sikumana Health Center in Kupang City can be explained that the lower the health service based on Reability the risk of dissatisfaction is 0.5 times higher than that of the health service based on Reability

Patient satisfaction based on responsiveness at the Sikumana Community Health Center in Kupang City. Increasingly not having health services based on Responsiveness will have a risk of dissatisfaction 0.5 times higher than those having health services based on Responsiveness

Patient Satisfaction based on Assurance at the Sikumana Health Center in Kupang City is obtained. The lack of health services based on Assurance will have a risk of dissatisfaction 0.5 times higher than those who have health services based on Assurance $(\mathrm{OR}=0.5, \mathrm{CI}=95 \%)$

Patient Satisfaction based on Empathy (Empathy) at the Community Health Center in Sikumana Kupang was obtained. Having no health services based on Empathy would have a risk of dissatisfaction 0.4 times higher than those who had health services based on Empathy.

Inpatient Health Services at Health Facilities I Level Against BPJS Patient Satisfaction In the Sikumana puskesmas in Kupang, data obtained that the better the services provided by health workers, the higher the patient satisfaction.

\section{REFERENCES}

Adik, Wibowo dan Tim Kesehatan Masyarakat di Indonesia. Konsep Aplikasi Tantangan Tahun 2014. Hal $477-478$

Answar. A. 2000. Pengantar Administrasi Kesehatan. Edisi ketiga. Binarupa Aksara. Jakarta: Indonesia. Hal 33

Aguswina. 2011. Karakteristik Pasien dan kualitas hidup pasien gagal ginjal kronik yang menjalani terapi. Skripsi fakultas keperawatan universitas respati. Yogyakarta. Hal 48

BPJS Kesehatan, Badan Penyelenggara Jaminan Kesehatan Nasional. www.BPJS-Kesehatan.go.id. Diakses tanggal 10 Mei 2019

Budiman. S. 2010. Hubungan Status Demografi dengan Kepuasan Masyarakat tentang Pelayanan Jamkesmas di Wilayah Puskesmas Tanjung Sari Kabupaten Bogor. Skripsi Universitas Indonesia. Jakarta: Indonesia. Hal 7

2013. Hubungan Status Demografi Dengan Kepuasan Masyarakat Tentang Pelayanan Jamkesmas Di Wilayah Puskesmas Tanjungsari Kabupaten Bogor tahun 2010", Jurnal Kesehatan Kartika, Vol

Hasbullah Thabrany. 2015. Jaminan Kesehatan Nasional. Edisi Kedua. Hal 45

Hidayat, Azis. AA. 2010. Riset Keperawatan Penelitian Kuantitatif. Jakarta: Salemba Humanika Irawan, Handi. 10 Prinsip Kepuasan Pelanggan. 2002. PT Elex Media Computindo : Jakarta.

Kepmenkes, RI. 2013. Buku Pegangan Sosialisasi Jaminan Kesehatan Nasional (JKN) dalam sistem Jaminan Sosial Nasional. Pusat Pembiayaan dan Jaminan Kesehatan Kementrian Kesehatan. R.I 
LPPM Stikes Bina Sehat PPNI. 2017. Buku Panduan Penyusunan KTI dan Skripsi. Mojokerto:LPPM Lupioadi. Hamdani. 2006. Manajemen Pemasaran jasa. Jakarta :Salemba

Manual Pelaksanaan JKN-BPJS 2014. Kesehatan diakes dari (http://www.sappk.itb.ac.id) diakses tanggal 14 Mei 2019. Hal 47

Moenir. 2006. "Manajemen Pelayanan Umum Di Indonesia”.Jakarta : Bumi Aksara

Muninjaya, 2004. Manajemen kesehatan.Jakarta : Penerbit Buku Kedokteran EGC: 220-234

Novita resha vianti. 2016. Analisis kepuasan pasien bpjs (badanpenyelenggarajaminan sosial) terhadap pelayanan kesehatan di instalasi rawat inap (iri) bangsal dahlia rsud ungaran. Semarang

Notoadmodjo, Soekidjo. 2010. Metodelogi Penelitian Kesehatan. Rineka Cipta: Indonesia hal 29

2012. Ilmu Perilaku Kesehatan. Rineka Cipta: Indonesia hal 76-117

Nursalam.2001. Manajemen Keperawatan, Aplikasi dalam praktek keperawatan Profesional. Jakarta: Salemba Medika.

2016. Metodelogi Penelitian Ilmu Keperawatan Pendekatan Praktis. Jakarta: Salemba Medika

Presiden, RI. UndanUndang RI no 40 tahun 2004 tentang Sistem Jaminan Sosial. Staff. UGM.ac.id. 2004. Diakses pada tanggal 29 April 2019

Ringkasan Eksekutif Laporan Program dan Laporan Keuangan Jaminan Sosial Kesehatan Tahun 2016. Akses tanggal 10 Mei 2019

Sinulingga. 2010. Metode Penelitian. Edisi 3. Medan: USU Press

Soeroso, Santoso. 2011. Manajemen Sumber Daya Manusia di Rumah Sakit. EGC: Jakarta Indonesia

Sudarmi, Dwi. 2010. Hubungan Karakteristik Pasien dengan Kepuasan terhadap Mutu Pelayanan Rawat Inap di Bidan RSUD Kabupaten Waled. Skripsi Jakarta: UI. Hal 9-37

Sudjarwo, H.S. 2014. Pengobatan Umum. Jakarta: Salemba Medika

Sugiyono. 2016. Metode Kuantitatif. Bandung: Alfabeta

Sulastomo. 2013. Manajemen Kesehatan. Gramedia Pustaka Utakma: Jakarta Indonesia Hal 39

Supranto,2001. Pengukuran tingkat Kepuasan Pelanggan untuk Menaikkan Pangsa Pasar. Jakarta: Rineka Cipta

S.Supriyanto, M.Sc. \& Ernawati 2010. Pemasaran Industri Jasa Kesehatan. Penerbit CV Andi Offset : Yogyakarta.

Thabrany, Hasbullah. 2015. Jaminan Kesehatan Nasional. PT Raja Grafindo Prasada. Jakarta: Indonesia. Hal 98

Tjiptono, F. Diana, A. 2013. Total Quality Manajemen Edisi Revisi. Penerbit Andi. Yogyakarta: Indonesia. Hal 98

Undang-undang RI no 36 tahun 2009. Tentang Kesehatan Biro Hukum Departemen Kesehatan RI. Jakarta: Indonesia Jakarta Indonesia. Hal 34

Zeithaml and bitner, 2000. Analisis Kepuasan Pasien Rawta Inap terhadap kualitas Pelayanan. Universitas Sanata. Dharma 